\title{
Sistem Pendidikan Indonesia Pada Masa Orde Lama (Periode 1945-1966)
}

Muhammad Rijal Fadli, Dyah Kumalasari

Program Studi Pendidikan Sejarah, Pascasarjana, Universitas Negeri Yogyakarta

\begin{abstract}
Abstrak
Artikel ini membahas tentang sistem pendidikan masa Orde Lama dimana pendidikan masa ini dimulai dari Periode 1945-1950 dan Periode 1950-1966. Penelitian ini menggunakan metode History (Sejarah) dengan tahapan-tahapan: Heuristik, Kritik sumber (kritik intern dan kritik ekstern), Interpretasi dan Historiografi. Hasil kajian membahas bahwa pendidikan pada masa Orde Lama diharapkan mampu menentukan tujuan pendidikan Indonesia ke arah yang lebih jelas dan maju. Dengan tujuan pendidikan jelas maka bisa mengarahkan ke pencapaian kompetensi-kompetensi yang dibutuhkan serta metode pembelajaran yang kondusif dan efektif. Berdasarkan tujuan tersebut pada masa Orde Lama banyak dikeluarkannya kebijakan-kebijakan di dalam bidang pendidikan yang digunakan untuk merencanakan dan mengatur pendidikan. Pasca kemerdekaan pendidikan Indonesia berlandaskan pada Pancasila dan UUD 1945, salah satunya terdapat pada pasal 31 UUD 1945 telah mengatur mengenai sistem pendidikan nasional. Tahun-tahun selanjutnya ditetapkan juga tentang pendidikan nasional yang diatur dalam UU No. 4/1950 yang kemudian disempurnakan (jo) menjadi UU No. 12/1954 tentang dasar-dasar pendidikan dan pengajaran di sekolah. Pada 1961 diatur UU No. 22/1961 tentang Pendidikan Tinggi, dilanjutkan dengan UU No.14/1965 tentang Majelis Pendidikan Nasional, dan UU No. 19/1965 tentang Pokok-Pokok Sitem Pendidikan Nasional Pancasila.
\end{abstract}

Kata Kunci: Sistem, Pendidikan, Orde Lama, Indonesia

\section{Pendahuluan}

\begin{tabular}{rcr} 
& Perkembangan & \multicolumn{2}{c}{ pemerintahan } \\
bangsa Indonesia dimulai sejak
\end{tabular}
diproklamirkan kemerdekaan 17 Agustus 1945. Proklamasi kemerdekaan merupakan tonggak penting dalam sejarah bangsa Indonesia. Sebagai negara yang independen, maka bangsa Indonesia perlu menyusun sistem kehidupan berbangsa dan bernegaranya berdasarkan Pancasila dan UUD 1945. Di antara sistem kehidupan tersebut tersusun sebuah sistem pendidikan yang diinginkan oleh bangsa Indonesia bagi seluruh rakyatnya (Ismail, 2016: 143-144). Setelah Proklamasi Kemerdekaan Indonesia 17 Agustus 1945, bangsa Indonesia melakukan banyak perubahan yang tidak hanya terjadi dalam bidang pemerintahan saja, tetapi juga dalam bidang pendidikan. Perubahan yang terjadi dalam pendidikan merupakan perubahan yang bersifat mendasar, yaitu perubahan menyangkut penyesuaian kebijakan pendidikan dengan dasar dan cita-cita suatu bangsa yang merdeka dan negara yang ingin berdiri sendiri (Rifa'i, 2016: 122).

Sehingga untuk penyesuaian itu dengan melihat cita-cita bangsa Indonesia, bidang pendidikan mengalami perubahan. Terutama dalam landasan filosofi pendidikan, tujuan pendidikan, sistem pendidikan, dan kesempatan belajar yang diberikan kepada rakyat Indonesia. Tujuannya supaya semua elemen 
masyarakat Indonesia dapat merasakan pendidikan dari pendidikan rendah sampai pendidikan tinggi. Melihat bahwa pancasila sebagai dasar dan falsafah negara Indonesia, seperti yang tertera dalam pembukaan Undang-Undang Dasar 1945, yang dijadikan landasan utama pendidikan Indonesia. Walaupun dalam kurun waktu yang tidak begitu lama, kurang lebih 1945-1950 dan 1950-1966 negara Indonesia telah mengalami beberapa kali perubahan Undang-Undang Dasar. Namun untuk dasar falsafah negara tidak mengalami perubahan.

Oleh karenanya, Pancasila menjadi landasan utama pendidikan Indonesia (Gunawan, 1995: 31-32). Pada saat itu dibentuk badan pembantu Presiden yaitu KNIP yang ditugaskan untuk menggodok bentuk dan pelaksanaan pendidikan nasional. Pada akhirnya 29 Desember 1945 hasil kerja KNIP tersebut diserahkan kepada pihak kementerian pendidikan, pengajaran, dan kebudayaan.

Sedangkan pokok pendidikan dan pengajaran baru di Indonesia sebagai realisasi usaha pembaharuan pendidikan dan pengajaran hasil kerja KNIP tersebut, diantaranya untuk menyusun masyarakat baru, memperkuat persatuan, metode yang berlaku di sekolah hendaknya berdasarkan sistem (Rifa'i, 2016: 122-124). Dengan demikian, pelaksanaan pendidikan di Indonesia pada masa awal kemerdekaan memiliki landasan falsafah Pancasila dan landasan Konstitusi berupa UUD 1945. Pada pasal 31 UUD 1945, berbunyi 1). Tiap warga negara berhak mendapat pengajaran, 2). Pemerintah mengusahakan sistem pengajaran nasional yang diatur dengan UU. Landasan dasar negara yang digunakan pemerintah Orde lama untuk menyusun dan melaksanakan sistem pendidikan nasional.

Melihat pemerintahan masa Orde lama melakukan perubahan diantaranya dalam pendidikan. Seperti diketahui setelah KMB (Konferensi Meja Bundar) pada 1949 maka terbentuklah Republik Indonesia Serikat. Di dalam RIS diaturnya mengenai pendidikan dan pengajaran dan didalam RIS juga diatur tentang pendidikan nasional. Dengan begitu, maka sistem pendidikan pada masa Orde Lama tidak jauh beda dengan masa sebelumnya, tetapi dalam masa Orde Lama menfokuskan kepada pendidikan dan pengajaran serta mengatur tentang pendidikan nasional.

Maka semuanya dalam bidang pendidikan periode 1945-1966 semuanya telah diatur dalam UUD yang berdasarkan Pancasila. Artikel ini akan membahas tentang sistem pendidikan pada masa Orde Lama, hal ini melihat periode pendidikan dari awal kemerdekaan sampai masa Orde Lama, kurun waktunya dibagi menjadi dua periode yaitu: Periode 1945-1950 dan Periode 1950-1966.

\section{Sistem Pendidikan Indonesia Masa Orde Lama}

Pada saat dicetuskan dasar negara yaitu Pancasila sebagai landasan utama 
negara Indonesia oleh Soekarno 1 Juni 1945, maka ketentuan yuridis konstitusional tersebut dijadikan konstruksi hukum yang tentunya mengandung konsekuensi formal, fungsional, dan impratif. Pancasila dijadikan pijakan sebagai norma dasar dan norma tertinggi di dalam kehidupan berbangsa dan bernegara di negera republik Indonesia. Pancasila adalah ideologi negara dan ideologi bangsa Indonesia.

Pancasila adalah identitas dan karakteristik bangsa atau keperibadian nasional yang perwujudannya secara melembaga sebagai sistem pancasila yang menjiwai setiap keperibadian bangsa, pandangan hidup (keyakinan bangsa) sistem kenegaraaan dan masyarakat Indonesia (Zulkarnain, 2017: 61). Landasan dan visi pendidikan masa Orde lama ketika itu diharapkan mampu menentukan tujuan pendidikan yang jelas. Oleh karena itu, tujuan pendidikan yang jelas pada gilirannya akan mengarahkan ke pencapaian kompetensi yang dibutuhkan serta metode pembelajaran yang efektif.

Pada akhirnya, kelak pendidikan mampu menjawab tuntutan untuk mensejahterakan masyarakat dan kemajuan bangsa. Pada awal kemerdekaan, pembelajaran di sekolah-sekolah lebih ditekankan pada semangat nasionalisme dan membela tanah air (Tim Uny: 76). Pada masa ini penekanan pendidikan kepada isu nasionalisasi dan ideologisasi. Penekanan pada kedua bidang tersebut tidak lain karena masa tersebut masa krusial pasca kemerdekaan, dimana banyak konflik yang mengarah pada separatisme dan terjadi interplay (tarik ulur) antara pihak yang sekuler dengan agamis (Sarnoto, 2012: 33). Revolusi nasional meletus pada tanggal 17 Agustus 1945 yang dikenal dengan Proklamasi Kemerdekaan. Dengan ini maka tercapailah kemerdekaan yang telah lama diidamkan bangsa Indonesia.

Proklamasi mampu mematahkan belenggu penjajahan dan menimbulkan hidup baru dilapangan apa saja salah satunya di bidang pendidikan, dirasakan perlu mengubah sistem pendidikan sesuai dengan suasana baru (Ahmadi, 1987: 78). Sehingga ada usaha perencanaan dalam pendidikan dan pengajaran yang telah dipersiapkan pada hari-hari terakhir penjajahan Jepang menjadi modal dan pedoman pertama dilapangan pendidikan. Pendidikan masa awal kemerdekaan berlandaskan Pancasila yang merupakan falsafah negara. Meski baru penentuan saja karena belum dijelaskan bagaimana meletakkan dasar itu pada tiap pelajaran (Somarsono Moestoko, 1986: 145).

Senada dengan lika-liku perjalanan sejarah bangsa dan negara Indonesia sejak di Proklamasikan Kemerdekaan Indonesia pada tanggal 17 Agustus 1945 sampai sekarang. Maka, sejarah pendidikan Indonesia pada masa Orde Lama dapat dilihat sesuai dengan pembagian kurun waktu yang ditandai dengan peristiwa 
penting dan tonggak sejarah sebagai pengingat, diantaranya periode 1945-1950 dan Periode 1950-1966. Adapun secara berurutan akan diterangkan tentang sistem pendidikan pada periode tersebut.

\section{A. Periode 1945-1950}

Sistem persekolahan sesudah Indonesia merdeka yang berdasarkan satu jenis sekolah untuk tiga tingkat pendidikan seperti pada zaman Jepang tetap diteruskan. Sedangkan rencana pembelajaran pada umumnya sama dan bahasa Indonesia ditetapkan sebagai bahasa pengantar untuk sekolah. Buku-buku pelajaran yang digunakan adalah buku hasil terjemahan dari bahasa Belanda ke dalam bahasa Indonesia yang sudah dirintis sejak zaman Jepang (Moestoko, 1986: 17). Adapun sistem pendidikan yang berlaku sejak tahun 1945-1950 adalah sebagai berikut:

\section{Pendidikan Rendah}

Pendidikan yang terendah di Indonesia sejak awal kemerdekaan yang disebut dengan Sekolah Rakyat (SR) lama pendidikan semula 3 tahun menjadi 6 tahun. Tujuan pendirian SR adalah selain meningkatkan taraf pendidikan pada masa sebelum kemerdekaan juga dapat menampung hasrat yang besar dari mereka yang hendak bersekolah.

Mengingat kurikulum SR diatur sesuai dengan putusan Menteri PK \& K tanggal 19 November 1946 No 1153/Bhg A yang menetapkan daftar pelajaran SR menekankan terhadap pelajaran bahasa dan berhitung. Hal ini dapat telihat bahwa dari 38 jam pelajaran seminggu, 8 jam adalah untuk bahasa Indonesia, 4 jam untuk bahasa daerah dan 17 jam untuk berhitung (kelas IV, V dan VI). Tercatat sejumlah 24.775 buah SR pada akhir tahun 1949 di seluruh Indonesia (Sjamsudin dkk, 1993: 18).

\section{Pendidikan Guru}

Dalam periode antara tahun 19451950 dikenal tiga jenis pendidikan guru (SGB, SGC, SGA) yaitu sebagai berikut (Rifa'i, 2016: 136-137):

a) Sekolah Guru B (SGB) lama pendidikan 4 tahun dan tujuan pendidikan guru untuk sekolah rakyat. Murid yang diterima adalah tamatan SR yang akan lulus dalam ujian masuk sekolah lanjutan. Pelajaran yang diberikan bersifat umum untuk di kelas I, II, III, sedangkan pendidikan keguruan baru diberikan di kelas IV. Untuk kelas IV ini juga dapat diterima tamatan sekolah SMP, SPG dipimpin oleh seorang kepala sekolah yang membawahinya sejumlah guru dan diantaranya merupakan tenaga tidak tetap karena memang sangat kekuarangan guru tetap. Adapun sistem ujian pelaksanaannya dipecah menjadi dua yaitu, perta ditempuh di kelas II dan ujian kedua di kelas IV.

b) Sekolah Guru C (SGC) berhubung kebutuhan guru SR yang mendesak 
maka terasa perlunya pembukaan sekolah guru yang dalam tempo singkat dapat menghasilkan. Untuk kebutuhan tersebut didirikan sekolah guru dua tahun setelah SR dan di kenal dengan sebutan SGC tetapi karena dirasakan kurang bermanfaat kemudian ditutup kembali dan diantaranya dijadikan SGB.

c) Sekolah guru A (SGA) karena adanya anggapan bahwa pendidikan guru 4 tahun belum menjamin pengetahuan cukup untuk taraf pendidikan guru, maka dibukalah SGA yang memberi pendidikan tiga tahun sesudah SMP. Disamping Itu dapat diterima pelajar lulusan kelas III SGB. Mata pelajaran yang diberikan di SGA sama jenisnya dengan mata pelajaran yang diberikan di SGB hanya penyelenggaraannya lebih luas dan mendalam.

\section{Pendidikan Umum}

Ada dua jenis pendidikan umum yaitu sekolah menengah pertama (SMP) dan sekolah menengah Tinggi (SMT).

a) Sekolah Menengah Pertama (SMP) seperti halnya pada zaman Jepang, SMP mempergunakan rencana pelajaran yang sama pula. Tetapi dengan keluarnya surat keputusan menteri PP \& K tahun 1946, maka diadakannya pembagian A dan B mulai kelas II sehingga terdapat kelas II A, II B, III A dan III B. Di bagian A diberikan juga sedikit ilmu alam dan ilmu pasti. Tetapi lebih banyak diberikan pelajaran bahasa dan praktek administrasi. Di bagian B sebaliknya diberikan Ilmu Alam dan Ilmu Pasti.

b) Sekolah Menengah Tinggi (SMT). Kementerian PP \& K hanya mengurus langsung SMT yang ada di Jawa terutama yang berada di kota-kota, seperti Jakarta, Bandung, Semarang, Yogyakarta, Surakarta, Surabaya dan Cirebon. SMT di Luar Jawa berada di bawah pengawasan pemerintah daerah, berhubung sulitnya perhubungan dengan pusat, SMT merupakan pendidikan tiga tahun setelah SMP dan setelah lulus dapat melanjutkan ke perguruan tinggi. Mengenai rencana pelajaran belum jelas dan yang diberikan adalah rencana pelajaran dalam garis besar saja. Karena pada waktu itu masih harus menyesuaikan dengan keadaan zaman yang masih belum stabil. Demikian rencana pembelajaran yang berlaku, yaitu (1). isinya memenuhi kebutuhan nasional, (2). bahasa pengantarnya adalah bahasa Indonesia dan (3). mutunya setingkat dengan SMT menjelang kemerdekaan. Ujian akhir dapat diselenggarakan oleh masing-masing sekolah selama belum ada ujian Negara. Tetapi setelah tahun 1947 baru berlaku ujian negara tersebut. Dapat dimaklumi 
apabila bobot ujian penghabisan negara yang pertama kalinya diadakan masih sangat minim karena pelajaran pun bersifat darurat (Sjamsudin dkk, 1993: 19-20).

\section{Pendidikan Kejuruan}

Pendidikan kejuruan fokus pada pendidikan ekonomi dan pendidikan kewanitaan:

a) Pendidikan ekonomi: pada awal kemerdekaan pemerintah baru dapat membuka sekolah dagang yang lama, pendidikannya tiga tahun sesudah Sekolah Rakyat. Sekolah dagang ini bertujuan untuk memenuhi kebutuhan tenaga administrasi atau pembukuan. Penyelenggaraan sekolah dagang tersebut dilaksanakan oleh inspektur sekolah dagang.

b) Pendidikan Kewanitaan: sesudah kemerdekaan dimana pemerintah membuka Sekolah Kepandaian Putri (SKP) dan pada tahun 1947 sekolah guru kepandaian putri (SGKP) yang lama pelajaranya empat tahun setelah SMP atau SKP (Rifa'i, 2016: 138-139).

\section{Pendidikan Teknik}

Seperti sekolah lain, keadaan Sekolah Teknik tidak teratur karena disamping pelajarnya sering terlibat dalam pertahanan negara, sekolah tersebut kadang juga dipakai sebagai pabrik senjata. Sekolah Teknik di Solo misalnya, dikerahkan untuk membuat senjata yang sangat diperlukan kendali apa adanya. Menurut Tim UNY (tanpa tahun: 85-86) memaparkan sekolah teknik yang ada pada masa itu, antara lain:

a) Kursus Kerajinan Negeri (KKN). Sekolah/kursus ini satu tahun lamanya dan merupakan pendidikan teknik terendah berdasarkan SR enam tahun. KKN terdiri atas jurusanjurusan: kayu, besi, anyaman, perabot rumah, las dan batu.

b) Sekolah Teknik Pertama (STP). Tujuannya adalah mendapatkan tenaga tukang yang terampil tetapi disertai dengan pengetahuan teori. Lama pendidikan dua tahun sesudah SR dan terdiri atas jurusan kayu, batu, keramik, perabot rumah, anyaman, besi ,listrik, mobil, cetak, tenun kulit, motor, ukur tanah dan ngecor.

c) Sekolah Teknik (ST). Mempunyai tujuan mendidik tenaga pengawasan bangunan. Lama pendidikan dua tahun setelah STP atau SMP bagian B dan meliputi jurusan bangunan gedung, bangunan air dan jalan, bangunan radio, bangunan kapal, percetakan dan pertambangan.

d) Sekolah Teknik menengah (STM). Bertujuan mendidik tenaga ahli teknik dan pejabat teknik menengah. Lama pendidikan empat tahun setelah SMP bagian B atau ST dan terdiri atas jurusn bangunan gedung, bangunan sipil, bangunan kapal, bangunan 
mesin, bangunan mesin, bangunan listrik, bangunan mesin kapal, kimia, dan pesawat terbang.

e) Pendidikan guru untuk sekolah teknik. Tujuannya untuk memenuhi keperluan guru sekolah teknik, dibuka sekolah/kursus untuk mendidik guru yang menghasilkan:

1) Ijazah A Teknik (KGSTP) guna mengajar dengan wewenang penuh pada STP dalam jurusan bangunan sipil, mesin, listrik dan mencetak.

2) Ijazah B I Teknik (KGST) untuk mengajar dengan wewenang penuh pada ST/STM kelas I dalam jurusan bangunan sipil, bangunan gedung dan mesin.

3) Ijazah B II Teknik guna mengajar dengan wewenang penuh pada STM dalam jurusan bangunan sipil, gedung, mesin dan listrik.

\section{Pendidikan Tinggi}

Periode 1945-1950 kesempatan untuk meneruskan studi pendidikan tinggi semakin terbuka lebar bagi warga negara tanpa syarat. Lembaga pendidikan ini berkembang pesat. Tetapi karena pelaksanaannya dilakukan perjuangan fisik, maka perkuliahan sering di sela-sela waktu dalam perjuangan garis depan.

Lembaga pendidikan yang ada adalah Universitas Gajah Mada, beberapa sekolah tinggi dan akademi di Jakarta (daerah kependudukan) Klaten, Solo dan Yogyakarta. Sistem persekolahan dan tujuan dari masing-masing tingkat pendidikan diatas diatur dalam UU No 4 Tahun 1950 bab $\mathrm{V}$ pasal 7 sebagai berikut (Tim Uny, tanpa tahun: 86-87):

Tentang jenis pendidikan dan pengajaran dan maksudnya, yakni:

a) Pendidikan dan pengajaran taman kanak-kanak bermaksud menuntun tumbuhnya rohani dan jasmani kanak-kanak sebelum masuk sekolah rendah.

b) Pendidikan dan pengajaran rendah bermaksud menuntun tumbuhnya rohani dan jasmani kanak-kanak, memberikan kesempatan kepadanya guna mengembangkan bakat dan kesukaannya masing-masing dan memberikan dasar pengetahuan, kecakapan, dan ketangkasan baik lahir maupun batin.

c) Pendidikan dan pengajaran menengah umum bermaksud melanjutkan dan meluaskan pendidikan dan pengajaran yang diberikan di sekolah rendah. Tujuannya untuk mengembangkan cara hidup serta membimbing kesanggupan murid sebagai anggota masyarakat. Selain itu, mendidik tenaga ahli dalam berbagai lapangan khusus sesuai dengan bakat dan kebutuhan masyarakat atau mempersiapkan bagi pendidikan dan pengajaran tinggi. 
d) Pendidikan dan pengajaran tinggi bermaksud memberikan kesempatan pelajar untuk menjadi orang yang dapat memelihara kemajuan ilmu dan kemajuan hidup kemasyarakatan.

e) Pendidikan dan pengajaran kepada orang-orang dalam keadaan kekurangan, baik jasmani maupun rohani supaya dapat memliki hidupnya lahir batin yang layak.

\section{Pendidikan Tinggi Republik}

Perkembangan pendidikan tinggi sesudah proklamasi kendati mengalami berbagai tantangan, tetapi tidak juga dapat dipisahkan dari perjuangan mempertahankan kemerdekaan. Menginta hal tersebut salah satu kekuatan dari seluruh rakyat Indonesia. Sejak awal kemerdekaan di Jakarta merupakan daerah pendudukan Belanda, berdiri sekolah Tinggi kedokteran sebagai kelanjutan Ika Daigaku zaman Jepang. Pada bulan November 1946 dibuka pula Sekolah Tinggi Hukum serta filsafat dan sastra.

Setelah aksi agresi militer I kedua lembaga pendidikan tinggi terakhir itu di tutup oleh belanda sehingga secara resmi sudah tidak ada lagi. Dengan demikian pendidikan tinggi waktu itu terpecah menjadi dua, yaitu Pendidikan Tinggi Republik dan Pendidikan Tingkat Tinggi Pendudukan Belanda. Tetapi kuliah masih dilanjutkan di rumah dosen sehingga merupakan semacam kuliah privat. Sebelum agresi militer I di Malang terdapat pula lembaga pendidikan tinggi Republik. Demikian pula terdapat sekolah tinggi kedokteran hewan sekolah tinggi teknik di Bandung dipindahkan ke Yogyakarta (Sjamsudin dkk, 1993: 11).

Sementara itu berturut-turut pendirian lembaga Perguruan Tinggi Republik tahun 1945-1950 adalah:

a) Sekolah Tinggi Republik didirikan pada 17 Februari 1946 oleh Kementerian Pengajaran dan Kebudayaan Indonesia di Yogyakarta.

b) Balai Perguruan Tinggi Gadjah Mada didirikan pada 3 Maret 1946 oleh Yayasan Balai Perguruan Tinggi Gadjah Mada, yang terdiri dari Fakultas Hukum dan Fakultas Kesusteraan di Yogyakarta.

c) Perguruan Tinggi Kedokteran dan Kedokteran Gigi didirikan pada Februari 1946 di Malang.

d) Perguruan Tinggi Kedokteran II didirikan pada 4 Maret 1946 di Solo.

e) Perguruan Tinggi Kedokteran I didirikan 5 Maret 1946 di Klaten.

f) Fakultas Pertanian dan Fakultas Farmasi berdiri pada 27 September di Klaten. Semua perguruan tinggi yang tercantum pada No. 4, 5 dan 6 berada di bawah Balai Perguruan Tinggi Republik Indonesia di Klaten.

g) Perguruan Tinggi Kedokteran Hewan didirikan pada November 1946 oleh Kementerian Kemakmuran Republik 
Indonesia di Bogor. Namun dilancarkannya aksi agresi militer I oleh Belanda pada Juli 1947, perguruan tinggi tersebut dipindahkan ke Klaten. Demikian juga perguruan tinggi di Malang.

h) Universitas Gadjah Mada didirikan pada 19 Desember 1949 di Yogyakarta, terdiri dari enam fakultas (Rifa'i, 2016: 141-142).

\section{Pendidikan Tingkat} Tinggi

\section{Pendudukan Belanda}

Atas prakarsa pihak Belanda pada bulan Januari 1946 didirikan suatu Universitas Darurat (NOOD Universiteit), yang terdiri dari lima fakultas yaitu fakultas kedokteran, hukum, sastra dan filsafat dan pertanian di Jakarta dan fakultas teknik di Bandung. Pada bulan Maret 1947 oleh pemerintah Belanda secara resmi nama Universitas Darurat diganti nama Universitas Indonesia (Universiteit Van Indonesie).

Tahun 1947 universitas tersebut di perluas dengan fakultas ilmu pasti dan alam di Bandung, kedokteran hewan di Bogor, Kedokteran di Surabaya dan Ekonomi di Makasar (Ujung Pandang). Pada bulan Maret 1948 fakultas pertanian di pindahkan ke Bogor (Tim UNY, tanpa tahun: 89). Melihat situasi dan kondisi bangsa Indonesia, bukti nyata pengaruh kecamuk politik dan perjuangan dalam mempertahankan kemerdekaan. Bangsa Indonesia telah mengalami perubahan ketatanegaraan dan UUD 1945 diganti dengan konstitusi sementara Republik Indonesia Serikat (RIS). Pada waktu itu, Indonesia bagian dari negara Republik Indonesia Serikat, telah mengalami perubahan sistem pemerintahan. Tetapi landasan dasar negara tetap Pancasila dan yang mengalami perubahan masuk pada tujuan pendidikan.

Kemudian tanggal 5 April 1950 dikeluarkan UU No. 4 tahun 1950 mengenai dasar-dasar pendidikan dan pengajaran di sekolah oleh Presiden. Di dalam UU No. 4 tahun 1950 bab II pasal 3 disebutkan tujuan pendidikan nasional Indonesia adalah membentuk manusia yang susila yang cakap dan warga negara yang demokratis serta bertanggung jawab tentang kesejahteraan masyarakat dan tanah air (Sedana Arta, 2015: 114). Hal ini berarti bahwa setiap sistem persekolahan pada waktu itu harus dapat menanamkan dan mengembangkan sifatsifat demokratis pada anak didiknya (Hartono, 2017: 87).

Dengan demikian, tujuan pendidikan tersebut mencerminkan sikap nasionalisme dan demokratis atau penghargaan kemerdekaan individu, masyarakat untuk membentuk bangsa. Diketahui melihat kebelakang bahwa pada masa sebelum kemerdekaan pada zaman kolonial Hindia-Belanda, sistem persekolahan hanya didasarkan dengan 
sistem golongan, baik golongan bangsa maupun status sosial. Setelah Proklamasi Kemerdekaan, sistem persekolahan di Indonesia memberi kesempatan belajar kepada semua lapisan masyarakat sesuai yang termaktub dalam UUD 1945 bab XIII pasal 31 ayat 1 berbunyi setiap warga negara berhak mendapat pengajaran.

Selanjutnya dalam UU Pendidikan dan Pengajaran tahun 1950 bab XI pasal 17 menyebutkan bahwa setiap warga negara Republik Indonesia mempunyai hak yang sama untuk diterima menjadi murid suatu sekolah, apabila memenuhi persyaratan dari sekolahnya. Dengan demikian pemerintahan Indonesia telah melakukan revolusi di dalam sistem pemerintahannya. Misalnya, dalam bidang pendidikan pemerintah telah memberikan kesempatan kepada semua lapisan masyarakat untuk menempuh pendidikan dari pendidikan rendah sampai pendidikan tinggi.

Sampai-sampai pemerintah melihat kondisi pendidikan Islam juga pada masa orde lama, sehingga diberikan kebijakan tersendiri oleh pemerintah yang perannya di berikan kepada Departemen Agama dan mulai resmi berdiri 3 Januari 1946. Lembaga ini secara intensif memperjuangkan sistem dan kebijakan pendidikan Islam di Indonesia. Secara lebih spesifik, usaha ini ditangani oleh suatu bagian khusus yang mengurusi masalah pendidikan agama (Maksum, 1999: 123). Madrasah dalam pendidikan Islam dianggap lembaga penyelenggara pendidikan dan diakui oleh negara secara formal pada tahun 1950.

Secara resmi diatur dalam UndangUndang No. 41950 tentang dasar-dasar Pendidikan dan Pengajaran di sekolah pasal 10 menyebutkan bahwa belajar di sekolah agama yang telah mendapat pengakuan departemen agama, sudah dianggap memenuhi kewajiban belajar. Untuk mendapat pengakuan dari departemen agama, madrasah harus memberikan pelajaran agama sebagai mata pelajaran pokok paling sediki enam jam seminggu secara teratur selain mata pelajaran umum (Mudzakkir, 2015: 56).

\section{B. Periode 1950-1966}

Pada periode ini difokuskan antara kurun waktu 1950-1966. Seperti diketahui sesudah KMB pada 1949 terbentuk Republik Indonesia Serikat (RIS). Di dalam RIS diatur mengenai pendidikan dan pengajaran. Di dalam UUD RIS juga diatur tentang pendidikan nasional. Menilik kebijakan pendidikan nasional di era ini dimulai dari pasal 30 UUDS 1950 RI diantaranya, yaitu 1). Tiap-tiap warga negara berhak mendapat pengajaran, 2). Memilih pengajaran yang akan diikuti adalah bebas, 3). Mengajar adalah bebas, dengan tidak mengurangi pengawasan penguasa yang dilakukan terhadap itu menurut peraturan UU (Rifa'i, 2016: 159). 
Menurut Supomo, ayat 1 pasal ini berasal dari rumusan pasal 31 ayat 1 UUD 1945. Ayat 2 sama dengan bunyi pasal 29 ayat 2 dari konstitusi RIS ayat 3 dari pasal ini rumusannya sama dengan pasal 29 ayat 12 konstitusi RIS. Diketahui salah satu hal yang menentukan masa orde lama berkaitan dengan kebijakan pendidikan adalah terciptanya atau terwujudnya UndangUndang No. 4 tahun 1950 tentang dasardasar pendidikan dan pengajaran di sekolah untuk seluruh Indonesia.

Semuanya dijelaskan dibeberapa sub yaitu di bab II pasal 3 menjelaskan mengenai tujuan pendidikan nasional dan bab III pasal 4 menjelaskan mengenai dasar pendidikan nasional (Rifa'i, 2016: 160). Masa revolusi pendidikan nasional mulai meletakkan dasar-dasarnya. Masa revolusi sangat terasa serba terbatas. Tetapi bangsa kita dapat melaksanakan pendidikan nasional sebagaimana yang diamanatkan dalam UUD 1945.

Kita dapat merumuskan Undang Undang Pendidikan No. 4/1950 junto No. 12/ 1954. Kita dapat membangun sistem pendidikan yang tidak kalah mutunya. Para pengajar, pelajar melaksanakan tugasnya dengan sebaik-baiknya walaupun serba terbatas. Dengan segala keterbatasan itu memupuk pemimpin-pemimpin nasional yang dapat mengatasi masa pancaroba seperti rongrongan terhadap Negara Kesatuan Republik Indonesia. Sayang akhir era ini, pendidikan kemudian dimasuki oleh politik praktis atau mulai dijadikan kendaraan politik. Pada masa itu dimulai pendidikan indoktrinasi yaitu menjadikan pendidikan sebagai alat untuk mempertahankan kekuasaan orde lama. Pada Orde Lama sudah mulai diadakan ujian-ujian negara yang terpusat dengan sistem Kolonial yang serba ketat tetapi tetap jujur dan mempertahankan kualitas. Hal ini didukung jumlah sekolah belum begitu banyak dan guru-guru yang ditempa pada zaman kolonial.

Pada zaman itu siswa dan guru dituntut disiplin tinggi. Guru belum berorientasi kepada yang material tetapi kepada yang ideal. Citra guru sebagai pahlawan tanpa tanda jasa yang diciptakaan era orde baru sebenarnya telah dikembangkan pada orde lama. Kebijakan yang diambil orde lama dalam bidang pendidikan tinggi yaitu mendirikan universitas setiap provinsi (Tim UNY, tanpa tahun: 90).

Kebijakan ini bertujuan untuk lebih memberikan kesempatan memperoleh pendidikan tinggi. Pada waktu itu pendidikan tinggi yang bermutu terdapat di Pulau Jawa seperti UI, IPB, ITB, Gajah Mada, dan UNAIR, sedangkan di provinsi-provinsi karena kurangnya persiapan dosen dan keterbatasaan sarana dan prasarana mengakibatkan kemerosotan mutu pendidikan tinggi mulai terjadi. Secara umum pendidikan orde lama sebagai wujud interpretasi pasca kemerdekaan di bawah 
kendali kekuasaan Soekarno cukup memberikan ruang bebas terhadap pendidikan. Pemerintahan yang berasaskan sosialisme menjadi rujukan dasar bagaimana pendidikan akan dibentuk dan dijalankan demi pembangunan dan kemajuan bangsa Indonesia di masa mendatang.

Prinsipnya konsep sosialisme dalam pendidikan memberikan dasar bahwa pendidikan merupakan hak semua kelompok masyarakat tanpa memandang kelas social (Yamin, 2009: 87). Pada masa ini Indonesia mampu mengekspor guru ke negara tetangga. Banyak generasi muda yang di sekolahkan di luar negeri dengan tujuan agar kelak dapat kembali ke tanah air untuk mengaplikasikan ilmu yang di dapat. Tidak ada halangan ekonomis yang merintangi seseorang untuk belajar di sekolah, karena diskriminasi dianggap sebagai tindakan kolonialisme.

Pada saat itu merupakan era setiap orang merasa bahwa dirinya sejajar dengan yang lain, serta setiap orang memiliki hak untuk mendapatkan pendidikan. Orde lama berusaha membangun masyarakat sipil yang kuat, yang berdiri di atas demokrasi, kesamaan hak dan kewajiban antara sesama warga negara, termasuk dalam bidang pendidikan. Sesungguhnya ini amanat UUD 1945 yang menyebutkan salah satu cita-cita pembangunan nasional adalah mencerdaskan kehidupan bangsa. Banyak pemikir yang lahir pada masa itu. Sebab ruang kebebasan dibuka dan tidak ada yang mendikte peserta didik. Melihat perkembangan politik saat itu, mempengaruhi jalannya kebijakan pendidikan nasional adalah sejak 1959. Indonesia berada di bawah gelora Manipol dan USDEK. Manipol dan USDEK telah menjadi dewa dalam bidang kehidupan lainnya. Termasuk dalam pendidikan. Keputusan Presiden No. 145 tahun 1965 merumuskan tujuan pendidikan nasional pendidikan Indonesia sesuai dengan Manipol dan USDEK. Manusia sosialis Indonesia adalah cita-cita utama setiap usaha pendidikan Indonesia.

Lebih jauh perkembangan pendidikan Indonesia masa orde lama kebijkan pendidikan nasional muncul sebuah kebijakan yang dikenal dengan Sapta Usaha Tama dan Pancawardhana tertuang dalam intruksi PP \& K No. 1 tahun 1959. Sapta Usaha Tama berisi tentang: penertiban aparatur dan usaha Kementerian PP \& K, menggiatkan kesenian dan olahraga, mengharapkan usaha halaman, mengharuskan penabungan, mewajibkan usaha-usaha koperasi, mengadakan kelas masyarakat, membentuk regu kerja di kalangan SLA dan universitas.

Sedangkan Pancawardhana atau lima pokok perkembangan yang oleh misi UNESCO untuk Indonesia diterjemahkan dalam bahasa Inggris The Five Principles of Education yang berisikan 1). Perkembangan cinta bangsa dan tanah air, moral nasional, 
internasional, dan keagamaan, 2). Perkembangan inteligensi, 3). Perkembangan emosional-artistik atau rasa keharusan dan keindahan lahir batin, 4). Perkembangan keprigelan (kerajinan) tangan serta 5). Perkembangan jasmani (Rifa'i, 2016: 177-178). Tilaar (1995: 103105) menyimpulkan secara konstitusional sistem pendidikan dalam era ini didasarkan kepada pengaturan sebagai berikut:

1. Undang-Undang pokok pendidikan No. 4 tahun 1950 juncto No. 12 tahun 1954.

2. Undang-Undang No. 2 tahun 1962 tentang Perguruan Tinggi.

3. Penetapan Presiden No. 5 tahun 1965.

Pengaruh Undang-Undang ini sangat terasa sekali terhadap sistem pendidikan Indonesia seperti halnya dalam pendidikan perguruan tinggi dalam perkembangannya sangatlah baik. Adanya Undang-Undang ini dalam perguruan tinggi swasta untuk pertama kalinya mengenal tingkat kedudukan perguruan tinggi swasta yaitu terdaftarkan, diakui, dan disamakan. Karena sebelumnya perguruan tinggi tidak mendapatkan kedudukan seperti itu.

Selanjutnya, dalam rangka mewujudkan pendidikan nasional, melalui Penetapan Presiden Indonesia No. 19 tahun 1965 mengenai Pokok-Pokok Sistem Pendidikan Nasional Pancasila. Diantaranya dirumuskan kembali tentang dasar asas pendidikan nasional, tujuan, isi moral, dan politik pendidikan nasional. Menariknya dari rumusan tersebut, tugas pendidikan nasional dalam revolusi Indonesia adalah menghimpun kekuatan progresif revolusioner berporoskan Nasakom (Rifa'i, 2016: 187). Jelas bahwa sudah mengetahui ke arah mana sistem pendidikan nasional itu dibawa, meskipun dalam perumusan dasar asasnya tetap berlandaskan kepada Pancasila, ditambah embel-embel ManipolUSDEK. Sehingga dalam sistem pendidikan nasional Pancasila tetap tujuan dan jiwa kurikulum dalam pendidikan Indonesia.

Ketidakadanya nuansa kepentingan politik sektoral tertentu untuk menjadikan pendidikan sebagai alat negara maupun kaum dominan pemerintah. Soekarno pernah berkata:

....sungguh alangkah hebatnya kalau tiap-tiap guru di perguruan taman siswa itu satu persatu adalah Rasul Kebangunan!, Hanya guru yang dadanya penuh dengan jiwa kebangunan dapat menurunkan kebangunan ke dalam jiwa sang anak (Yamin, 2009: 92).

Dari perkataan Soekarno sangat jelas bahwa pemerintahan orde lama menaruh perhatian serius yang tinggi untuk memajukan bangsanya melalui pendidikan. Di bawah menteri pendidikan Ki Hadjar Dewantara dikembangkan pendidikan dengan sistem among berdasarkan asas kemerdekaan, kodrat alam, kebudayaan, kebangsaan, dan kemanuasiaan yang dikenal sebagai Panca Dharma Taman Siswa dan semboyan ing ngarso sung tulodho, ing madyo mangun karso, tut wuri handayani. Pada 1950 dicetuskan pertama kali 
peraturan pendidikan nasional yaitu UU No. 4/1950 yang disempurnakan (jo) menjadi UU No. 12/1954 tentang dasar pendidikan dan pengajaran di sekolah. Pada 1961 dirumuskan lagi UU No. 22/1961 tentang Pendidikan Tinggi, dilanjutkan UU No.14/1965 tentang Majelis Pendidikan Nasional, dan UU No. 19/1965 tentang pokok sistem pendidikan nasional pancasila. Masa akhir pendidikan Presiden Soekarno, $90 \%$ bangsa Indonesia berpendidikan SD (Tim UNY, tanpa tahun: 92).

Dengan demikian, sistem pendidikan pada masa orde lama telah banyak dipengaruhi kondisi politik bangsa Indonesia saat itu. Pasca Indonesia lepas dari penjajahan dan berhasil mempertahankan kemerdekaan dari ancaman penjajah Belanda dengan perjanjian KMB. Sehingga Indonesia berdasarkan semangat kebangsaan tengah belajar terus menerus untuk membangun sebuah negara dan belajar untuk berdemokrasi.

Dalam menjalankan pemerintahan Indonesia sering melakukan kejadian euforia. Kesalahan itu semua terbukti dari kestabilan pemerintahan saat itu dengan sistem parlemennya. Dengan banyaknya partai saling sikut menyikut untuk berkuasa, maka parlemen sulit bekerja sama dengan baik, positif, maju dan progresif, untuk membentuk rancangan dan penerapan pendidikan nasional yang baik dan kuat. Sampai akhirnya Soekarno mengeluarkan Dekrit Presiden 1959 untuk membubarkan parlemen dan kembali ke UUD 1945. Sebagai gantinya UUDS 1950 dengan fungsi untuk menstabilkan kondisi politik nasional saat itu.

\section{Penutup}

Pendidikan pada masa orde lama di awali sejak Proklamasi Kemerdekaan berlandaskan Pancasila yang merupakan falsafah negara. Meskipun baru tahap penentuan saja sebab belum dijelaskan bagaimana meletakkan dasar itu pada settiap pelajaran. Senada dengan dinamika perjalanan sejarah bangsa pasca Proklamasi sampai sekarang. Sejarah pendidikan Indonesia masa orde lama dapat dilihat sesuai dengan pembagian kurun waktu ditandai dengan peristiwa penting dan tonggak sejarah, yaitu Periode 1945-1950 dan Periode 1950-1966. Sistem pendidikan periode 1945-1950 seperti zaman Jepang tetap diteruskan, sedangkan rencana pembelajaran umumnya sama dan bahasa Indonesia ditetapkan sebagai bahasa pengantar untuk sekolah.

Akan tetapi oleh pemerintahan Indonesia diberlakukan beda. Diketahui pada periode ini sudah ditetapkan setiap warga negara Indonesia berhak mendapatkan pengajaran dari semua lapisan masyarakat. Berbeda dengan zaman Kolonial yang mendapatkan pengajaran hanya golongan tertentu. Sistem pendidikan periode ini mulai dari pendidikan rendah 
(Sekolah Rakyat) sampai pendidikan tinggi (Sekolah Tinggi Republik). Sedangkan periode 1950-1966 hanya melanjutkan dan mengimplementasikan kebijakan mengenai sistem pendidikan yang telah di atur sedemikian rupa.

Semuanya sudah di atur mengenai pendidikan nasional sejak pasca Proklamasi Kemerdekaan tertera di dalam UU No. 4/1950 yang kemudian disempurnakan (jo) menjadi UU No. 12/1954 tentang dasardasar pendidikan dan pengajaran di sekolah. Pada 1961 diatur UU No. 22/1961 tentang Pendidikan Tinggi, dilanjutkan dengan UU No.14/1965 tentang majelis pendidikan nasional, dan UU No. 19/1965 tentang pokok sistem pendidikan nasional pancasila.

\section{Daftar Pustaka}

Ahmadi. (1987). Pendidikan dari Masa Ke Masa. Bandung: CV. Armico.

Gunawan, Ary H. (1995). KebijakanKebijakan Pendidikan di Indonesia. Jakarta: Bina Aksara.

Hartono, Yudi. (2017). Pendidikan Nasional dan Kualitas Manusia Indonesia Dalam Perspektif Sejarah. Agastya: Jurnal Sejarah Dan Pembelajarannya, 7, 84-102.

Ismail. (2016).Politik Pendidikan Islam Orde Lama 1945-1965 (Study Kebijakan Pemerintah Dalam Penyelenggaraan Pendidikan Islam). Kabilah: Journal of Social Community, 1, 139-169.

Maksum. (1999). Madrasah: Sejarah dan Perkembangannya. Jakarta: Logos Wacana Ilmu.
Moestoko, Somarsono. (1986). Pendidikan Indonesia Dari Zaman Ke Zaman. Jakarta: Balai Pustaka.

Mudzakkir. (2015). Pendidikan Islam Masa Orde Lama Dan Orde Baru. Al Fatih, 4, 55-66.

Rifa'i, Muhammad. (2016). Sejarah Pendidikan Nasional: Dari Masa Klasik Hingga Modern. Yogyakarta: Ar-Ruzz Media.

Sarnoto, Ahmad Zain. (2012) Konsepsi Politik Pendidikan Di Indonesia. Educhild, 01, 30-40.

Sedana Arta, Ketut. (2015). Sejarah Pendidikan. Yogyakarta: Media Akademi.

Sjamsudin, Helius, dkk. (1993). Sejarah pendidikan di Indonesia: Zaman Kemerdekaan, 1945-1966. Jakarta: Departemen Pendidikan dan Kebudayaan.

Tilaar. (1995). 50 Tahun Pembangunan Pendidikan Nasional 1945-1995: Suatu Analisis Kebijakan. Jakarta: Gramedia.

Tim UNY. (Tanpa Tahun). Peta Jalan Pendidikan Indonesia. Yogyakarta: Universitas Negeri Yogyakarta.

Yamin, Moh. (2009). Menggugat Pendidikan Indonesia. Yogyakarta: Ar-Ruzz Media.

Zulkarnain. (2017). Filosofis Kurikulum Mata Pelajaran Sejarah Masa Orde Lama. HISTORIA: Jurnal Pendidik dan Peneliti Sejarah, 1, 57-62. 